\title{
Editorial \\ Selected Papers from the Second International Online Conference on Nanomaterials
}

\author{
Ana M. Díez-Pascual ${ }^{1, *(\mathbb{C})}$, Antonio Di Bartolomeo ${ }^{2}(\mathbb{D})$ and Guanying Chen ${ }^{3}(\mathbb{C})$ \\ 1 Universidad de Alcalá, Facultad de Ciencias, Departamento de Química Analítica, Química Física e Ingeniería \\ Química, Ctra. Madrid-Barcelona, Km. 33.6, 28805 Madrid, Spain \\ 2 Physics Department, University of Salerno, Via Giovanni Paolo II 132, 84084 Fisciano, Italy; \\ adibartolomeo@unisa.it \\ 3 School of Chemistry and Chemical Engineering, Harbin Institute of Technology, Harbin 150090, China; \\ chenguanying@hit.edu.cn \\ * Correspondence: am.diez@uah.es
}

\section{check for}

updates

Citation: Díez-Pascual, A.M.; Di Bartolomeo, A.; Chen, G. Selected

Papers from the Second International Online Conference on Nanomaterials. Nanomaterials 2022, 12, 302. https:// doi.org/10.3390/nano12030302

Received: 19 December 2021

Accepted: 7 January 2022

Published: 18 January 2022

Publisher's Note: MDPI stays neutral with regard to jurisdictional claims in published maps and institutional affiliations.

Copyright: (c) 2022 by the authors. Licensee MDPI, Basel, Switzerland. This article is an open access article distributed under the terms and conditions of the Creative Commons Attribution (CC BY) license (https:// creativecommons.org/licenses/by/ $4.0 /)$.
Nanomaterials have gained eminence in technological developments due to their tunable physical, chemical, and biological properties, such as wettability, electrical and thermal conductivity, magnetism, light absorption and emission, catalytic activity, and so forth, leading to devices with improved performance compared to their microscopic counterparts. They have at least a dimension in the 0.1 to $100 \mathrm{~nm}$ range, and are classified based on their size, composition, shape, and origin. Thus, four main categories can be distinguished based on their nature [1]: (1) carbon-based nanomaterials, which are found in morphologies such as ellipsoids or spheres, hollow tubes, or ultrathin sheets; fullerenes $\left(\mathrm{C}_{60}\right)$, carbon nanotubes (CNTs), carbon nanofibers, carbon black, graphene $(\mathrm{G})$, and its derivatives graphene oxide $(\mathrm{GO})$ and reduced graphene oxide (rGO) are in this category [2,3]. (2) Inorganicbased nanomaterials, which include metal [4] and metal oxide nanoparticles, such as $\mathrm{TiO}_{2}$, $\mathrm{SnO}$ and $\mathrm{ZnO}$ [5-7], and semiconductors, such as silicon, III-V compounds, transition metal dichalcogenides, Xenes, etc. [8]. (3) Organic-based nanomaterials, which include dendrimers, micelles, liposomes and polymer nanoparticles. (4) Composite-based nanomaterials, with one phase on the nanoscale dimension that can either combine nanoparticles with other nanoparticles or other structures such as metal-organic frameworks. The composites may be any combinations of carbon-, metal-, or organic-based nanomaterials with any form of metal, ceramic, or polymer bulk materials $[9,10]$.

This Special Issue collects fourteen selected papers from the Proceedings of the second International Online Conference on Nanomaterials, held on 15-30 November 2020 in Sciforum (https:/ / sciforum.net/conference/IOCN2020), an online platform for scholarly e-conferences and discussion groups that presents the most recent advances in the area of nanomaterials.

The articles present very different types of nanomaterials, such as gold nanorods [4], $\mathrm{WTe}_{2}$ nanocrystals [11], $\mathrm{CaCO}_{3}$ nanoparticles [12], ferromagnetic nanoparticles [13], $\mathrm{CuO}$ nanocrystals and single-walled carbon nanotubes [14], graphene [3], and GO derivatives [15].

Different techniques have been applied to characterize these nanomaterials, including X-ray diffraction, optical profilometry, cyclic voltammetry, IR and Raman spectroscopies, ellipsometry, dynamic light scattering (DLS), contact angle measurements, $\mathrm{N}_{2}$ adsorptiondesorption experiments, atomic force microscopy (AFM), ultraviolet-visible (UV-VIS), fluorescence, X-ray photoelectron (XPS) and electrochemical impedance (EIS) spectroscopies, scanning and transmission electronic microscopies (SEM and TEM).

Moreover, the developed materials can be used for a wide range of applications: (1) drug delivery systems to deliver gefitinib (GEF) and paclitaxel (PTXL) to treat breast cancer [12] or to release antibiotics such as ciprofloxacin, as well as some other small model drug compounds [16]; (2) materials for the removal of toxic contaminants in water, such as 
As, $\mathrm{Mn}, \mathrm{Cr}$, and Cd from ground water and natural water conditions [17]; (3) membrane catalysis with specific parameters [18]; (4) quaternary memory systems for applications in data storage and processing [19]; (5) electrochromic devices, which control optical properties such as optical transmission, absorption, reflectance, and/or emittance in a continual but reversible manner on the application of voltage [20]; (6) flexible electrodes with high optical transparency, low electrical resistance, and mechanical bending stability for use in flexible polymer-dispersed liquid crystal (PDLC) structures (7) in optoelectronic devices as well as outdoor displays, projection displays, switchable privacy glasses, energysaving windows, light shutters and so forth; and (8) hole transport layers in inverted perovskite solar cells.

The articles published in the Special Issue of the second International Online Conference on Nanomaterials (IOCN 2020) highlight the important role of nanomaterials for the progress of science, technology, and human healthcare. We expect that more and more researchers can join the open access ICON forum in the future to promote the development of nanoscience and nanotechnology.

Funding: This research received no external funding.

Data Availability Statement: Data sharing is not applicable to this article as no new data were created or analyzed in this study.

Conflicts of Interest: The authors declare no conflict of interest.

\section{References}

1. Jeevanandam, J.; Barhoum, A.; Chan, Y.S.; Dufresne, A.; Danquah, M.K. Review on nanoparticles and nanostructured materials: History, sources, toxicity and regulations. Beilstein J. Nanotechnol. 2018, 9, 1050-1074. [CrossRef] [PubMed]

2. Díez-Pascual, A.M. Effect of Graphene Oxide on the Properties of Poly(3-Hydroxybutyrate-co-3-Hydroxyhexanoate). Polymers 2021, 13, 2233. [CrossRef] [PubMed]

3. Kondrashov, I.; Komlenok, M.; Pivovarov, P.; Savin, S.; Obraztsova, E.; Rybin, M. Preparation of Copper Surface for the Synthesis of Single-Layer Graphene. Nanomaterials 2021, 11, 1071. [CrossRef] [PubMed]

4. Velimirovic, M.; Pancaro, A.; Mildner, R.; Georgiou, P.G.; Tirez, K.; Nelissen, I.; Johann, C.; Gibson, M.I.; Vanhaecke, F. Characterization of Gold Nanorods Conjugated with Synthetic Glycopolymers Using an Analytical Approach Based on spICPSFMS and EAF4-MALS. Nanomaterials 2021, 11, 2720. [CrossRef] [PubMed]

5. Díez-Pascual, A.M. Environmentally Friendly Synthesis of Poly(3,4-Ethylenedioxythiophene): Poly(Styrene Sulfonate)/SnO2 Nanocomposites. Polymers 2021, 13, 2445. [CrossRef] [PubMed]

6. Díez-Pascual, A.M.; Díez-Vicente, A.L. Antibacterial SnO2 nanorods as efficient fillers of poly(propylene fumarate-co-ethylene glycol) biomaterials. Mater. Sci. Eng. C Mater. Biol. Appl. 2017, 78, 806-816. [CrossRef] [PubMed]

7. Dimitrov, D.Z.; Chen, Z.F.; Marinova, V.; Petrova, D.; Ho, C.Y.; Napoleonov, B.; Blagoev, B.; Strijkova, V.; Hsu, K.Y.; Lin, S.H.; et al. ALD Deposited ZnO:Al Films on Mica for Flexible PDLC Devices. Nanomaterials 2021, 11, 1011. [CrossRef] [PubMed]

8. Di Bartolomeo, A. Emerging 2D materials and their van der Waals heterostructures. Nanomaterials 2020, 10, 579. [CrossRef] [PubMed]

9. Díez-Pascual, A.M.; Díez-Vicente, A.L. Multifunctional poly(glycolic acid-co-propylene fumarate) electrospun fibers reinforced with graphene oxide and hydroxyapatite nanorods. J. Mater. Chem. B 2017, 5, 4084-4096. [CrossRef] [PubMed]

10. Liu, B.-T.; Lin, H.-R.; Lee, R.-H.; Gorji, N.E.; Chou, J.-C. Fabrication and Characterization of an Efficient Inverted Perovskite Solar Cells with POSS Passivating Hole Transport Layer. Nanomaterials 2021, 11, 974. [CrossRef] [PubMed]

11. Buchkov, K.; Todorov, R.; Terziyska, P.; Gospodinov, M.; Strijkova, V.; Dimitrov, D.; Marinova, V. Anisotropic Optical Response of WTe2 Single Crystals Studied by Ellipsometric Analysis. Nanomaterials 2021, 11, 2262. [CrossRef] [PubMed]

12. Chemmalar, S.; Intan-Shameha, A.R.; Abdullah, C.A.C.; Ab Razak, N.A.; Yusof, L.M.; Ajat, M.; Gowthaman, N.S.K.; Bakar, M.Z.A. Synthesis and Characterization of Gefitinib and Paclitaxel Mono and Dual Drug-Loaded Blood Cockle Shells (Anadara granosa)-Derived Aragonite CaCO3 Nanoparticles. Nanomaterials 2021, 11, 1988. [CrossRef] [PubMed]

13. Detzmeier, J.; Königer, K.; Blachowicz, T.; Ehrmann, A. Asymmetric Hysteresis Loops in Structured Ferromagnetic Nanoparticles with Hard/Soft Areas. Nanomaterials 2021, 11, 800. [CrossRef] [PubMed]

14. Sapkota, K.P.; Islam, M.A.; Hanif, M.A.; Akter, J.; Lee, I.; Hahn, J.R. Hierarchical Nanocauliflower Chemical Assembly Composed of Copper Oxide and Single-Walled Carbon Nanotubes for Enhanced Photocatalytic Dye Degradation. Nanomaterials 2021, 11, 696. [CrossRef] [PubMed]

15. Sainz-Urruela, C.; Vera-López, S.; San Andrés, M.P.; Díez-Pascual, A.M. Graphene Oxides Derivatives Prepared by an Electrochemical Approach: Correlation between Structure and Properties. Nanomaterials 2020, 10, 2532. [CrossRef]

16. Jervis, P.J.; Hilliou, L.; Pereira, R.B.; Pereira, D.M.; Martins, J.A.; Ferreira, P.M.T. Evaluation of a Model Photo-Caged Dehydropeptide as a Stimuli-Responsive Supramolecular Hydrogel. Nanomaterials 2021, 11, 704. [CrossRef] [PubMed] 
17. Safi, S.R.; Gotoh, T. Simultaneous Removal of Arsenic and Manganese from Synthetic Aqueous Solutions Using Polymer Gel Composites. Nanomaterials 2021, 11, 1032. [CrossRef] [PubMed]

18. Myachina, M.; Gavrilova, N.; Poluboyarinova, K.; Nazarov, V. Molybdenum-Tungsten Blue Nanoparticles as a Precursor for Ultrafine Binary Carbides. Nanomaterials 2021, 11, 761. [CrossRef] [PubMed]

19. Sudsom, D.; Ehrmann, A. Micromagnetic Simulations of Fe and Ni Nanodot Arrays Surrounded by Magnetic or Non-Magnetic Matrices. Nanomaterials 2021, 11, 349. [CrossRef] [PubMed]

20. Mouratis, K.; Tudose, I.V.; Bouranta, A.; Pachiu, C.; Romanitan, C.; Tutunaru, O.; Couris, S.; Koudoumas, E.; Suchea, M. Annealing Effect on the Properties of Electrochromic V2O5 Thin Films Grown by Spray Deposition Technique. Nanomaterials 2020, $10,2397$. [CrossRef] [PubMed] 